\title{
Book Review: Indonesia: Twenty Years of Democracy
}

\section{Olle Törnquist ${ }^{1}$}

\author{
Indonesia: Twenty Years of Democracy \\ Author: Jamie. S Davidson \\ Cambridge: Cambridge University Press, 2018
}

Writing both succinctly and comprehensively about the rise, achievements, and challenges of Indonesian democracy since 1998 is difficult. Most scholars have opted for extensive books or focused on special themes or regions. Jamie Davidson has made an admirable effort in less than eighty accessible pages in a new series titled Cambridge Elements, which aims to combine "up-to-date overview of debates in the scholarly literature with original analysis and a clear argument". He focuses on politics, political economy, identity-based mobilisation, and arrives at three major conclusions. Firstly, that Indonesian democratisation is strong in a comparative perspective, especially with regard to elections and freedoms, but weak on a closer look. It is especially poor, he says, with regard to the impartial rule of law and public administration (i.e. corruption), plus increased vote buying due to staggering competition between candidates after closed-party lists were declared unconstitutional

Olle Törnquist is Professor of Political Science and Development Research at the University of Oslo. He has written widely since the 1970s on comparative radical politics and democracy, especially in Indonesia, parts of India, the Philippines, and Scandinavia. His recent books include Reinventing Social Democratic Development. Insights from Indian and Scandinavian Comparisons (with John Harriss et al.), NIAS Press, 2016, and Dilemmas of Popular Transactionalism: What are the Prospects Now for Popular Politics in Indonesia? (with Luky Djani et al.) PolGov, Universitas Gadjah Mada, 2017. 
in 2008. Secondly, that "democracy, and its related process of democratisation, is the most appropriate overarching framework for studying Indonesia". Thirdly, the previous focus on "change and continuities" in studies of Indonesia after Suharto "has run its course," as the twenty years since the fall of the Suharto regime constitutes a long enough period to qualify for specific research (pp. 4-5). Three phases are identified: one (labelled 'innovation') under presidents B.J. Habibie, Abdurrahman Wahid, and Megawati Sukarnoputri; another (labelled 'stagnation') under Susilo Bambang Yudhoyono, and a third (labelled 'polarisation') under Joko Widodo, or Jokowi.

At first sight, this is fine. However, during careful reading two problems become obvious. One is that the decision to abandon the focus on "change and continuities" is not based on a review of that framework (even a brief one). As such, it is difficult for the reader to take a stand. To the extent that the decision is to demote history, there are good reasons to object; take, for example, when Davidson neglects the legacy of suppression and violence, or the deep roots of the poor rule of law and corruption in the structural dynamics of Sukarno and the Army's 'Guided Democracy' and Suharto's 'New Order'.

The second problem is that the author neither really argues for his three main themes, nor for how they are analysed. Possibly, this is because he does not apply his own conclusion about democratisation as the organising principle. Aside from a statement that he wishes to focus on "tensions, inconsistencies, and contradictory puzzles" (p. 4), there is not even a brief analytical framework for analysing democracy and democratisation. Consequently, the author's motive for choosing specific conditions, actors, and dynamics to focus on remains unclear. The same is true for the scholarly arguments that 
are deemed worthy of attention. Davidson certainly accounts for interesting factors within his three main fields of politics, political economy, and identity-based mobilisation, to which we shall return. But, how are these fields and factors identified and related to each other in the context of democratisation? What scholarly results are considered and why? The reader simply does not know. Much of the critical scholarship on the problems and options of democratisation, especially Indonesian, is set aside.

An initial example is that Davidson identifies the weak rule of law (i.e. corruption) as the prime problem, but does not provide an argument countering the alternative conclusion (reached through extensive research) that the fundamental problems are poor organisation and representation of vital interests beyond those of the dominant groups, particularly if one wants to foster a better rule of law through democratic means. Second, Davidson identifies one crucial institutional obstacle to democracy-that parties must be present around the huge country to participate in even local elections - but does not present an argument to support his setting aside of the additional important challenge of enabling strategic socio-economic groups and citizens to organise and make a difference in mainstream politics. Third, Davidson presents his own important analyses of identity-based mobilisation as the third major theme in his book, but what are his arguments for not considering other forms of mobilisation, such as those based on the interests of workers (including domestic workers), farmers and fishermen? (Labour studies, for one, are mentioned only in a brief footnote.) Fourth, why is there no analysis of the most important effort at a broad democratic alliance for improved democratic policies, namely the successful struggle for universal public health reform? The causes of the failure to sustain this alliance is also not considered, even though this failure paved the way for conservative populism? Fifth, why are efforts to achieve equal and active citizenship to overcome Suharto's politics of "floating masses" and the continued politics of amnesia regarding suppression and mass killings not deemed worthy 
of attention in a discussion of Indonesia's democracy? Finally, why is the rise of Jokowi only explained in terms of decentralisation and local direct elections, ignoring the role of local civil society groups and social movements in building a successful social pact in his hometown (Solo), which caught the imagination of large numbers of people in Jakarta but could not be applied nationally? Davidson might have interesting reasons for these and other priorities, but why are they not even hinted at? We must sustain the primacy of intellectual deliberation against the suppositional mainstream within Indonesia studies.

Keeping such critical questions in mind, however, the reader may indeed benefit from Davidson's review of a number of other aspects of post-Suharto development in Indonesia, especially his sections on the political economy and 'identity-based mobilisations'. One example is Davidson's discussion about the consequences of the immediate decentralisation of politics and administration after 1998 , followed by a commodity boom that was driven significantly by the economic growth of China and India. On the one hand, one might conclude from Davidson, that decentralisation-along with the boom - saved Indonesia's establishment after the Asian economic crisis and turbulent political transition. The undermining of previous centralised authoritarianism provided a wide array of leaders and businesspersons with manoeuvring room. The oligarchs adjusted, and after some time, local strongmen substituted new business opportunities for regional rebellion. Moreover, the state gained fresh revenues, enabling President Yudhoyono in particular to foster stability and provide some handouts to voters among vulnerable sections of the population. On the other hand, much of the decentralisation and the increasing demand for commodities fostered primitive accumulation of capital, including predatory 
practices. To a large extent, economic growth was based on the plunder and extraction of natural resources. In contrast, investment in manufacturing and industry was less profitable, despite increasing demand as a result of privileged upper- and middle-class consumption. Most importantly, few new jobs were created, and the much-needed improvements to infrastructure lagged behind. In short, state-private partnerships flourished and most powerful actors were happy, but inclusive development was held back.

This brings to mind similar problems of fostering inclusive, rather than extractive, growth during and after the commodity boom in a number of other countries in the Global South. So far, Indonesia under Jokowi has avoided an Argentinian, Venezuelan, or Brazilian catastrophe, including by reducing fuel subsidies in favour of state-directed investments in the poorly developed infrastructure and some welfare reforms. But growth remains below the $7 \%$ that Jokowi aimed for; and more importantly-again, as Davidson underlines - the question is how many new jobs can be created and what will happen within the manufacturing and industry sectors. At the time of this review, media reports focus on senior ministers, servants, and state-enterprise leaders trying to attract foreign investments as China is becoming riskier and more expensive. To this and Davidson's factors, one might also add that Indonesia's more fundamental problem might be the weak and fragmented interestbased organisations among productive oriented capital and labour groups, who could otherwise negotiate inclusive development as well as the investment in improved workers' education and training plus productive welfare. Worst, neither reform-oriented populists nor their right wing equivalents have an answer to this crisis of representation.

Another example of the important processes that Davidson draws attention to is the combination of local extractive growth with rent-seeking activities and identity-based mobilisation. The rush for resources and funds, and the proliferation of new local district administrations, came with intensified identity politics. It would 
have been helpful to analyse this in a firmer historical framework, examining the reinvented elements of the colonial indirect rule of commodity production through strongmen and religious-cumethnic communities in contrast to the direct relations between citizens and the state sought by socialists and communists in the nationalist movement. Nonetheless, the best parts of Davidson's book do include elements of this perspective, especially his analysis of the rise of new movements based on (not always inclusionary) customary rule (adat), in addition to religious and ethnic identity politics. This partial resurgence of earlier dynamics, along with vigilante groups, comes with new mobilisation against the LGBT community and frequent support from sections of the oligarchs and military. As such, Davidson also adds important insights about attempts at weaken the Jokowi government, especially since 2016.

Davidson rounds up with an interesting discussion about "(w)ho and which strategic group might bring down Indonesia's democracy?" (p. 55) Most oligarchs, he contends, have good reasons to be sufficiently satisfied with their firm control of resources, electoral politics, and media. The military, while losing out initially, has regained control of its corporate interests and sustained its territorial organisation, which has enabled it to control people as well as local resources. Senior officers are also making headways within business and politics. Instead, according to Davidson, Islamic nationalism poses the largest threat. This, he adds, is not about Islam, which has long been compatible with Indonesian democracy, but Islamism. Worst, there is a possibility of horse-trading between antidemocratic Islamists, oligarchs, and military leaders, with politicians such as ex-general turned tycoon Prabowo Subianto in the forefront. To counter this, Davidson concludes, the creation of more jobs and a better rule of law are crucial priorities. Unsurprisingly, however, 
given his weak analysis of democratisation, he has nothing to say about who can foster such processes by way of strengthening and deepening democracy. 